\title{
Karakteristik Mineral Grafit Daerah Samaturu, Kabupaten Kolaka, Provinsi Sulawesi Tenggara
}

\author{
Khalifa Akbar ${ }^{1}$, Hasria $^{1 *}$, Suryawan Asfar ${ }^{1}$ \\ ${ }^{1}$ Jurusan Teknik Geologi, Universitas Halu Oleo, Kendari
}

\begin{abstract}
Abstrak
Mineral grafit merupakan salah satu bentukan dari unsur karbon. Mineral grafit memiliki banyak kegunaan dalam bidang teknologi, salah satunya pada baterai lithium ion yang sedang dikembangkan di Indonesia. Penggunaan mineral grafit semakin meningkat pada industri teknologi di dunia termasuk di Indonesia, namun mineral grafit di Indonesia masih harus diimpor dari luar negeri. Selain itu, mineral grafit memiliki kisaran harga jual 1.550-2.800 USD/ton untuk tipe vein, 700-10.000 USD/ton untuk tipe flake, dan 430-550 USD/ton untuk tipe amorf. Berdasarkan hal inilah eksplorasi mineral grafit di Indonesia perlu dilakukan. Penelitian ini bertujuan untuk mengetahui batuan yang mengandung mineral grafit beserta karakteristik dan sebaran mineral grafit di daerah penelitian Penelitian ini dilakukan di daerah Samaturu, karena mineral grafit dapat ditemukan pada Kompleks Malihan Paleozoikum. Metode penelitian yang digunakan yaitu pengamatan megaskopis, petrografi dan analisis SEM-EDS. Batuan yang dijumpai mengandung mineral grafit yaitu satuan litologi sekis muskovit yang memiliki persen karbon yang beragam. Mineral grafit yang dijumpai di daerah penelitian memiliki karaktersitik yaitu merupakan grafit natural yang kristalin, bentuk pipih dan saling mengikat, terbentuk oleh metamorfisme regional, tidak teratur pada hinge lipatan sehingga diketahui bahwa mineral grafit di daerah penelitian termasuk dalam tipe endapan flake graphite (grafit serpih).
\end{abstract}

Kata kunci: grafit; karakteristik; Samaturu; sekis.

\begin{abstract}
Graphite minerals are one form of the element carbon. Graphite minerals have many uses in the technology, one of which is on lithium-ion batteries that are being developed in Indonesia. The use of graphite minerals is increasing in the technology industry in the world, including in Indonesia, however, graphite minerals in Indonesia still have to be imported from abroad. In addition, graphite minerals have a selling price range of 1,550-2,800 USD / ton for the vein type, 700-10,000 USD / tonne for the flake type, and 430-550 USD / tonne for the amorphous type. Based on this, exploration of graphite minerals in Indonesia needs to be carried out. This study aims to determine the rock containing graphite minerals along with the characteristics and distribution of graphite minerals in the study area. This research was conducted in the Samaturu Area, because graphite minerals can be found in the Malihan Paleozoic Complex. The research method used is megascopic observation, petrography and SEM-EDS analysis. The rocks contained graphite minerals called muscovite schist unit which had various percentage of carbon content. In the study area, graphite minerals have characteristics, i.e. crystalline, flat and intertwined. Those graphites formed by regional metamorphism, irregular in the hinge folds, so that it is known that the graphite minerals in the study area are included in the type of flake graphite deposits.
\end{abstract}

Keywords: graphite; characteristics; Samaturu; schist.

\footnotetext{
*) Korerspondensi: hasriageologi@gmail.com
} 


\section{PENDAHULUAN}

Batuan metamorf sering kali tidak mendapat banyak perhatian oleh para geologis. Kurangnya atensi para geologis ini disebabkan oleh keterdapatan endapan mineral ekonomis yang minim pada batuan metamorf. Batuan metamorf memiliki salah satu endapan mineral yang cukup bernilai ekonomis dan memiliki banyak kegunaan dalam perkembangan teknologi. Mineral tersebut adalah mineral grafit.

Mineral grafit merupakan salah satu mineral dari unsur karbon selain mineral intan. Mineral grafit terbentuk secara alami sebagai tiga tipe dasar yaitu serpihan, urat, dan amorf. Semua memiliki struktur kristal, meskipun grafit tipe amorf adalah bahan karbon dengan tingkat keteraturan yang sangat rendah dalam struktur mikrokristalin (Fogg dan Boyle, 1987).

Mineral grafit dibedakan menjadi dua yaitu grafit alami dan sintetis. Penggunaan grafit secara tradisional digunakan sebagai bahan dasar pembuatan pensil. Penggunaan grafit pada teknologi baru dan berkembang saat ini digunakan pada baterai litium, reaktor nuklir, panel surya, dan semikonduktor (Crossley, 2000).

Mineral grafit dapat dijumpai pada batuan metamorfisme regional seperti genes, sekis, filit, batusabak, dan pada metamorfisme kontak seperti marmer dan endapan skarn (Yarangga dkk., 2017). Umumnya, dalam mencari keterdapatan mineral grafit, formasi geologi yang berupa batuan malihan dapat digunakan sebagai panduan dalam menentukan formasi pembawa mineral grafit. Indonesia mempunyai beberapa jalur batuan malihan terutama di Pulau Sulawesi, Pulau Sumatra, dan Pulau Kalimantan, sehingga menjadi potensi mineral grafit di Indonesia.

Berdasarkan Helmers dkk. (1989) batuan malihan pada Kompleks Malihan Mekongga disusun oleh sekis grafit-mika dan mika kuarsit dengan sisipan pualam. Berdasarkan (Rusmana dkk., 1993) dalam Peta Geologi Lembar Lasusua-Kendari, Sulawesi Tenggara, skala 1 : 250.000, daerah Samaturu tersusun atas Batuan Malihan Paleozoikum dengan jenis batuan yaitu sekis, genes, filit, kuarsit, batusabak, dan sedikit pualam serta batuan Pualam Paleozoikum dengan jenis batuan pualam dan batugamping terdaunkan. Berdasarkan Simandjuntak dkk. (1993) dalam Peta Geologi Lembar Kolaka, skala $1: 250.000$, daerah Samaturu tersusun atas
Kompleks Mekongga dengan jenis batuan yaitu sekis, genes, dan kuarsit serta satuan Aluvium. Berdasarkan Anggriawan (2016) di Desa Kaloloa, Kecamatan Samaturu, daerah ini tersusun atas batuan Formasi Pompangeo. Satuan batuan dari Formasi Pompangeo yang terdapat di daerah Samaturu yaitu satuan sekis, terdiri dari sekis mika, sekis klorit dan sisipan kuarsit dan satuan aluvium (Qa). Pada Formasi Pompangeo di Pegunungan Rumbia ditemukan satuan batuan sekis grafit, sekis mika, sekis klorit yang memiliki komposisi mineral yaitu muskovit, grafit, kuarsa, mineral lempung dan mineral opak (Hasria dkk., 2017; Hasria dkk., 2019).

Beberapa penelitian menunjukkan di wilayah Kabupaten Kolaka terdapat mineral grafit (Helmers dkk., 1989; Rusmana. dkk., 1993; Simandjuntak dkk., 1993; Anggriawan, 2016; Hasria dkk., 2019). Mineral grafit ini dapat ditemukan pada jenis batuan yaitu sekis, genes, filit, kuarsit dan batusabak yang merupakan penyusun dari kompleks metamorf di lengan tenggara Sulawesi khususnya pada daerah penelitian. Hal ini didasari oleh Kompleks Mekongga atau Batuan Malihan Paleozoikum yang terdapat sekis grafit-mika, sekis mika, dan sekis klorit yang mengandung mineral grafit.

Oleh karena itu, sangat penting melakukan penelitian tentang sebaran dan karakteristik tipe mineral grafit di daerah Samaturu sehingga diperoleh data dan informasi tentang batuan yang mengandung mineral grafit serta sebaran dan karakteristiknya di daerah Samaturu, Kabupaten Kolaka, Provinsi Sulawesi Tenggara.

\section{Tipe Endapan Mineral Grafit}

Grafit memiliki asal biogenik, terbentuk dari berbagai zat organik, seperti tanaman air dan darat, kerogen, bahan bitumen, dan sisa-sisa organik lainnya. Fragmen yang diidentifikasi struktur organik yang tertanam dalam batugamping, filit, batusabak, sekis, metaantrasit, dan semi-grafit membuktikan bukti genesis biogenik yang tak terbantahkan (Kwiecińska dan Petersen, 2004).

Grafit dapat berupa singenetik yang dibentuk melalui evolusi metamorf materi karbon tersebar dalam sedimen atau epigenetik yang berasal dari presipitasi karbon padat dari karbon jenuh cairan C-O-H (Kwiecińska dan Petersen, 2004).

Mineral grafit terbagi menjadi 3 tipe endapan berdasarkan Robinson dkk. (2017), yaitu: 
1. Grafit urat (vein graphite)

Berdasarkan Luque dkk. (2014), endapan grafit urat dikontrol secara struktural karena dihasilkan dari pengendapan dari cairan yang mengandung karbon yang disalurkan melalui sistem rekahan. Karena itu, endapan ini merekam transportasi karbon melalui kerak dan mantel. Cairan dan karbon yang mengandung karbon telah diakui dalam beragam proses geologi. Namun, endapan grafit urat dibatasi untuk granulite terranes facies dan batuan beku.

2. Grafit amorf (amorphous graphite)

Grafit jenis ini terbentuk dari lapisan batubara yang terkena proses metamorfosa, kental, umumnya massif dan berukuran kriptokristalin (Paul dalam Yarangga dkk., 2017). Ukuran, bentuk, kandungan karbon dan mineral pengotor tergantung pada awal terbentuknya lapisan batubara. Grafit ini umumnya mengandung $85 \%$ grafit.

3. Grafit serpih (flake graphite)

Berdasarkan Mitchell (1993) grafit serpih terbentuk sebagai kristal pipih, seperti lempeng, dengan sudut yang tajam (angular), bundar, atau tidak beraturan, tersebar keseluruh metasedimen yang berasal dari karbon. Endapan grafit serpih biasanya terikat strata, dengan lapisan atau lensa dari $30 \mathrm{~cm}$ hingga lebih dari 30 meter dan memanjang hingga 2 kilometer atau lebih. Tubuh bijih biasanya berbentuk tabular, kadang-kadang lenticular, dan terjadi secara lokal dengan bentuk tidak beraturan di zona hinge lipatan.

\section{Lokasi Penelitian}

Penelitian dilakukan di daerah Samaturu, Kabupaten Kolaka, Provinsi Sulawesi Tenggara yang umumnya berada pada Kompleks Mekongga (Rusmana dkk., 1993; Simandjuntak dkk., 1993). Daerah penelitian termasuk dalam peta geologi lembar Kolaka dan lembar Lasusua-Kendari. Lokasi penelitian tersusun atas Kompleks Malihan Paleozoikum (Pzm), Pualam Paleozoikum (Pzmm) dan Aluvium (Qa) (Gambar 1).

Tabel 1. Karakteristik komoditi grafit, deposit, dan penggunaanya (Robinson dkk., 2017).

\begin{tabular}{|c|c|c|c|c|}
\hline \multirow{2}{*}{ Karakteristik } & \multicolumn{4}{|c|}{ Tipe Komoditas } \\
\hline & Amorf & Flake & Lump atau Vein & Sintetik \\
\hline Tipe Deposit & Amof & Serpih diseminasi & Urat atau Vein & NA \\
\hline Kristalinitas & Mikrokristalin & Kristalin & Kristalin & $\begin{array}{c}\text { Mikrokristalin - } \\
\text { kristalin }\end{array}$ \\
\hline $\begin{array}{c}\text { Sifat } \\
\text { (Kristalinitas, } \\
\text { Bentuk) }\end{array}$ & $\begin{array}{c}\text { Agregat mikrokristalin } \\
\text { yang seperti tanah }- \\
\text { kompak. Berukuran }<4 \\
\mu \mathrm{m}\end{array}$ & $\begin{array}{c}\text { Kristal pipih berkembang } \\
\text { baik, dengan ukuran butir } \\
\text { antara } 40 \mu \mathrm{m} \text { dan } 4 \mathrm{~cm} \\
\text { (tetapi umumnya } \leq 1 \mathrm{~cm} \text { ), } \\
\text { dan ketebalan } 1 \text { sampai } \\
150 \mu \mathrm{m} .\end{array}$ & $\begin{array}{l}\text { Agregat Kristal kasar yang } \\
\text { saling berikatan. Tersedia } \\
\text { dalam bentuk bubuk hingga } \\
10 \mathrm{~cm}\end{array}$ & $\begin{array}{c}\text { Tersedia dalam } \\
\text { ukuran partikel } \\
\text { mulai dari bubuk } 2 \\
\mu \mathrm{m} \text { sampai } \\
\text { potongan } 2 \mathrm{~cm}\end{array}$ \\
\hline $\begin{array}{c}\text { Asal } \\
\text { Pembentukan }\end{array}$ & $\begin{array}{c}\text { Metamorfisme Kontak, } \\
\text { sering dengan intrusi } \\
\text { diabasik atau granitic, } \\
\text { dan (atau) } \\
\text { metamorfisme regional } \\
\text { dari sedimen karbon, } \\
\text { sering juga batubara }\end{array}$ & $\begin{array}{l}\text { Metamorfisme regional } \\
\text { dari sediman karbon pada } \\
\text { atau melebihi kondisi } \\
\text { fasies amfibolit }\end{array}$ & $\begin{array}{l}\text { Vein epigenetik dan lapisan } \\
\text { terbentuk dari cairan } \\
\text { metamorf pada batuan } \\
\text { metamorf tingkat tinggi, } \\
\text { biasanya granulit. }\end{array}$ & $\begin{array}{c}\text { Diproduksi dengan } \\
\text { perlakuan panas } \\
\text { (grafitisasi), atau } \\
\text { pengendapan kimia } \\
\text { dari, bahan } \\
\text { hidrokarbon diatas } \\
2.100^{\circ} \mathrm{C} \\
\end{array}$ \\
\hline Tubuh Bijih & $\begin{array}{l}\text { Lapisan, lapisan, dan } \\
\text { lensa dalam batuan } \\
\text { karbon, masing-masing } \\
\text { tebalnya beberapa meter } \\
\text { dan panjangnya ratusan } \\
\text { meter hingga beberapa } \\
\text { kilometer dan mungkin } \\
\text { teripat dan tersesarkan }\end{array}$ & $\begin{array}{l}\text { Lapisan yang saling } \\
\text { terikat; bentuk tabular } \\
\text { atau melensa, setebal } 33 \\
\text { m dan panjang ribuan } \\
\text { meter. Tidak teratur di } \\
\text { area hinge lipatan. } \\
\text { Lensanya memiliki } \\
\text { variabel internal konten } \\
\text { grafit dan antar lensa. }\end{array}$ & $\begin{array}{l}\text { Urat dan pengisian dalam } \\
\text { rekahan atau struktur } \\
\text { metamorf yang saling } \\
\text { memotong dan kontak } \\
\text { batuan. Ketebalan masing- } \\
\text { masing urat berkisar antara } \\
0,05 \text { hingga } 3 \mathrm{~m} \text {, meskipun } \\
\text { biasanga kurang dari } 0,3 \mathrm{~m} \text {, } \\
\text { dan meluas hingga ratusan } \\
\text { meter, meskipun jarang dari } \\
\text { puluhan meter. }\end{array}$ & NA \\
\hline
\end{tabular}




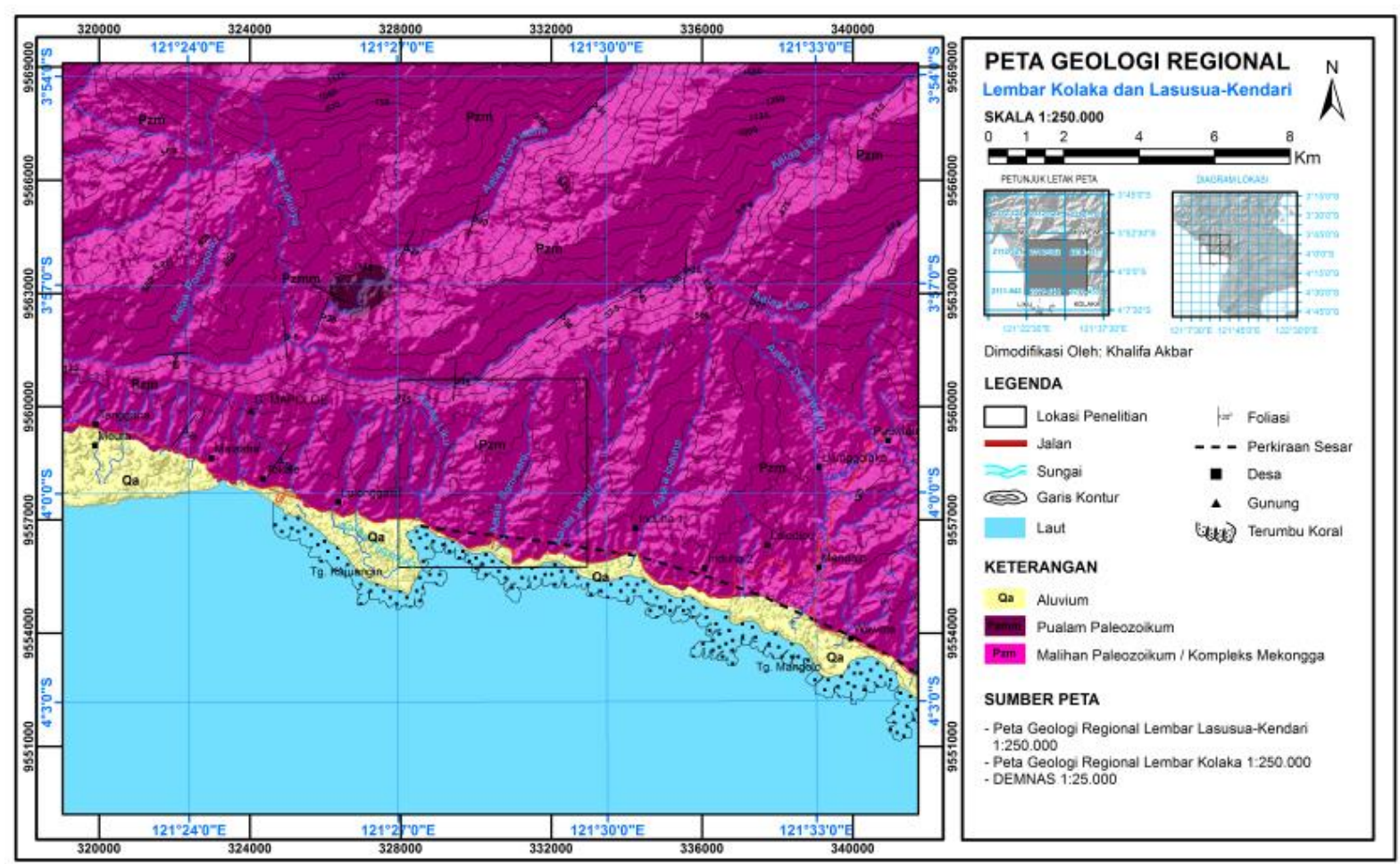

Gambar 1. Peta geologi regional Lembar Kolaka \& Lembar Lasusua-Kendari modifikasi dari Rusmana, dkk. (1993) dan Simandjuntak dkk. (1993).

\section{METODOLOGI}

Metode penelitian terdiri dari studi pustka, pengamatan dan pengambilan sampel yang representatif, analisis laboratorium serta analisis dan interpretasi data. Analisis laboratorium yang digunakan adalah analisis petrografi dan analisis SEM-EDS untuk menentuan jenis batuan yang mengandung grafit, sebaran batuan yang mengandung grafit serta penentuan karakteristik dan tipe endapan mineral grafit.

Analisis petrografi dari penelitian ini dilakukan terhadap sayatan tipis batuan yang merupakan hasil dari preparasi tujuh sampel batuan yang digunakan dalam analisis mikroskopis batuan. Proses preparasi sampel batuan ini menggunakan metode pemotongan batuan yang segar dan baik (padat dan kompak) yang kemudian dilakukan penipisan batuan hingga ketebalan $\pm 0,003 \mathrm{~mm}$. Sampel batuan yang diambil kemudian dianalisis melalui petrografi menggunakan mikroskop polarisasi untuk mengetahui tekstur, struktur dan komposisi mineralnya. Preparasi sayatan tipis ini dilakukan di Museum Geologi Bandung dan pengamatan mikroskopisnya dilakukan di Laboratorium Teknik Geologi, Fakultas Ilmu dan Teknologi Kebumian, Universitas Halu Oleo.

Analisis SEM-EDS menggunakan sampel batuan yang mengandung mineral grafit yang segar dan merupakan sampel yang sama dengan sampel dengan sampel analisis petrografi yaitu sampel stasiun 25 yang mewakili sampel sekis muskovit dan sampel stasiun 17 yang mewakili sampel sekis klorit. Data dari hasil analisis tersebut akan direkam oleh komputer dalam bentuk tabel. Analisis SEM-EDS ini dilakukan di Laboratorium SEM-EDS UPP Chevron, Institut Teknologi Bandung.

\section{HASIL PENELITIAN \\ Jenis Batuan}

Berdasarkan hasil pengamatan secara megaskopis di lapangan dan analisis petrografi, dilakukan pada 7 sampel batuan pada 7 stasiun yang berbeda, maka jenis batuan yang ditemukan di daerah Samaturu, yaitu sekis, muskovit, dan sekis klorit.

Secara megaskopis, sampel pada stasiun 9, 19, 25 dan 29 (Gambar 2) merupakan jenis batuan metamorf yang memiliki warna abu-abu gelap, dengan tekstur kristaloblastik berupa lepidoblastik, tersusun atas mineral mika, 
mineral grafit, mineral kuarsa dan mineral klorit. Indikasi gejala struktur pada sampel batuan ini menunjukan foliasi serta memperlihatkan struktur skistosik yang ditunjukan oleh mineral mika, kuarsa, dan grafit yang tersusun secara paralel. Berdasarkan hasil pengamatan, maka nama batuan ini ialah sekis mika (Travis, 1955).

Hasil petrografi memperlihatkan adanya mineral grafit, muskovit, klorit dan kuarsa yang menyusun batuan. Memiliki tekstur lepidoblastik yang ditunjukkan oleh mineral muskovit, grafit, dan klorit, serta tekstur granuloblastik yang ditunjukkan oleh mineral kuarsa sehingga membentuk struktur skistosik.
Kehadiran mineral grafit pada batuan sekis dapat ditandai dengan adanya warna absorbsi kehitaman yang berbentuk pipih. Mineral grafit hadir bersama mineral muskovit yang membentuk perselingan grafit-muskovit pada foliasi sekis muskovit. Persentase kehadiran mineral grafit yaitu $25 \%$ pada stasiun $9,30 \%$ pada stasiun $19,54 \%$ pada stasiun 25 , dan $25 \%$ pada stasiun 29.

Sampel pada stasiun 31 (Gambar 3) secara megaskopis, merupakan jenis batuan metamorf yang memiliki warna abu-abu gelap, dengan tekstur kristaloblastik berupa lepidoblastik, tersusun atas mineral mika, mineral kuarsa, dan
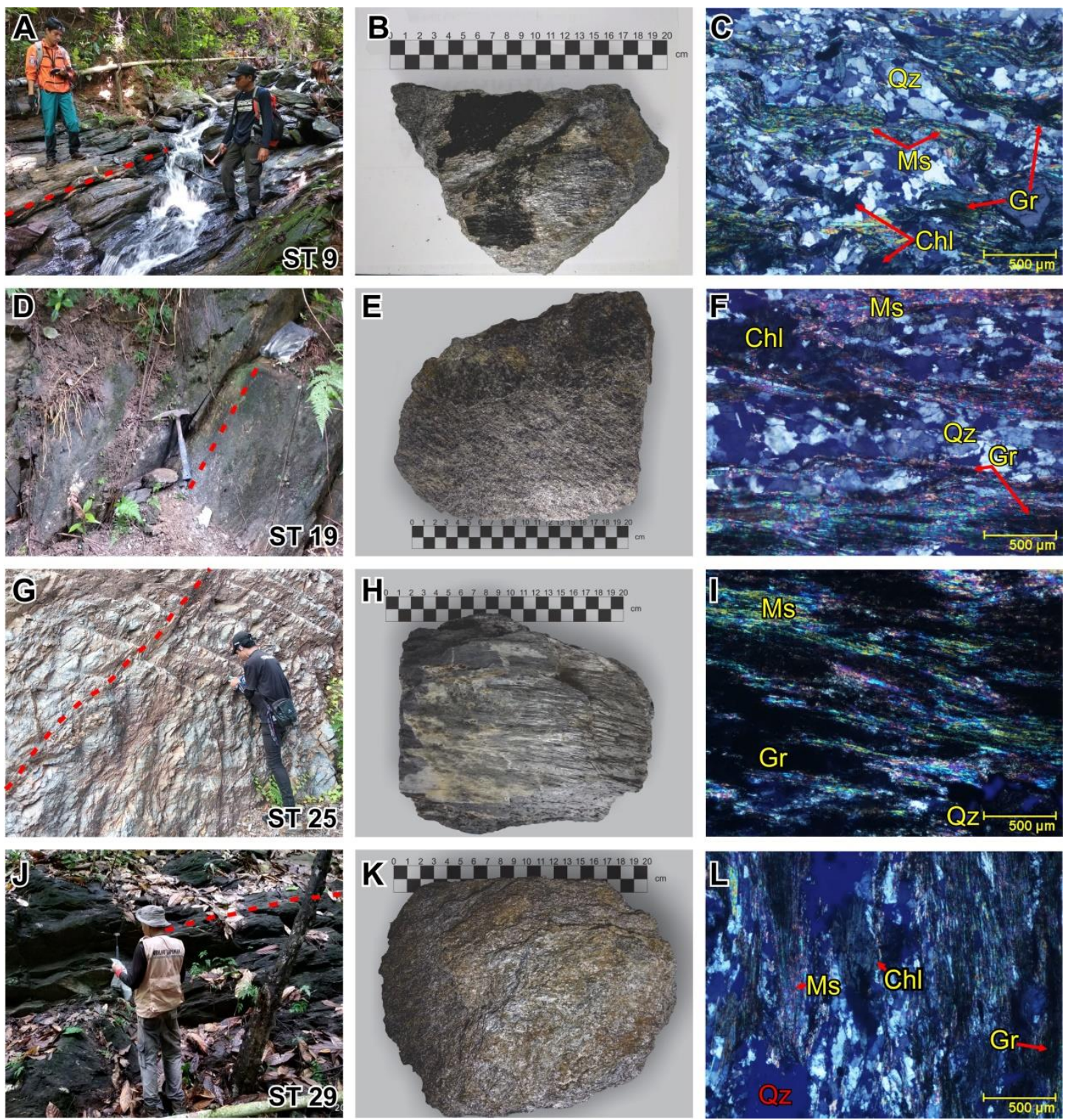

Gambar 2. Batuan metamorf dengan jenis sekis muskovit. (A, D, F, J) merupakan gambar singkapan, (B, E, H, K) merupakan gambar sampel hand specimen, dan (C, F, I, L) merupakan gambar sayatan tipis sampel batuan (nikol sejajar). Garis merah putus-putus menunjukkan foliasi pada singkapan. Gr= grafit, Ms= muskovit, Qz= kuarsa, dan $\mathrm{Chl}=$ klorit. 
mineral klorit. Indikasi gejala struktur pada sampel batuan ini menunjukan foliasi serta memperlihatkan struktur skistosik yang ditunjukan oleh mineral mika dan kuarsa yang tersusun secara paralel. Dari hasil pengamatan maka nama batuan ini ialah sekis mika (Travis, 1955).

Sayatan tipis pada sampel stasiun 31 (Gambar 3) memperlihatkan adanya mineral muskovit, klorit dan kuarsa yang menyusun batuan ini. Memiliki tekstur lepidoblastik yang ditunjukkan oleh mineral muskovit dan klorit, serta tekstur granuloblastik yang ditunjukkan oleh mineral kuarsa sehingga membentuk struktur skistosik. Pada batuan ini tidak dijumpai kehadiran mineral grafit.

Pada pada stasiun 3 dan stasiun 17 (Gambar 4) merupakan jenis batuan metamorf yang memiliki warna abu-abu kehijauan, sangat kompak, dengan tekstur heteroblastik berupa granoblastik dan lepidoblastik, ukuran kristal kasar, yang tersusun atas mineral kuarsa dan mineral klorit.

Indikasi gejala struktur pada sampel batuan ini menunjukan foliasi yang dibentuk oleh mineral klorit (lepidoblastik) dan mineral kuarsa (granoblastik). Dari hasil pengamatan maka nama batuan ini ialah sekis klorit (Travis, 1955).

Sayatan tipis pada sampel stasiun 3 memperlihatkan adanya mineral klorit dan kuarsa, sedangkan pada stasiun 17 memperlihatkan adanya mineral muskovit, klorit, dan kuarsa yang menyusun batuan ini.

Memiliki tekstur lepidoblastik yang ditunjukkan oleh mineral muskovit dan klorit, serta tekstur granuloblastik yang ditunjukkan
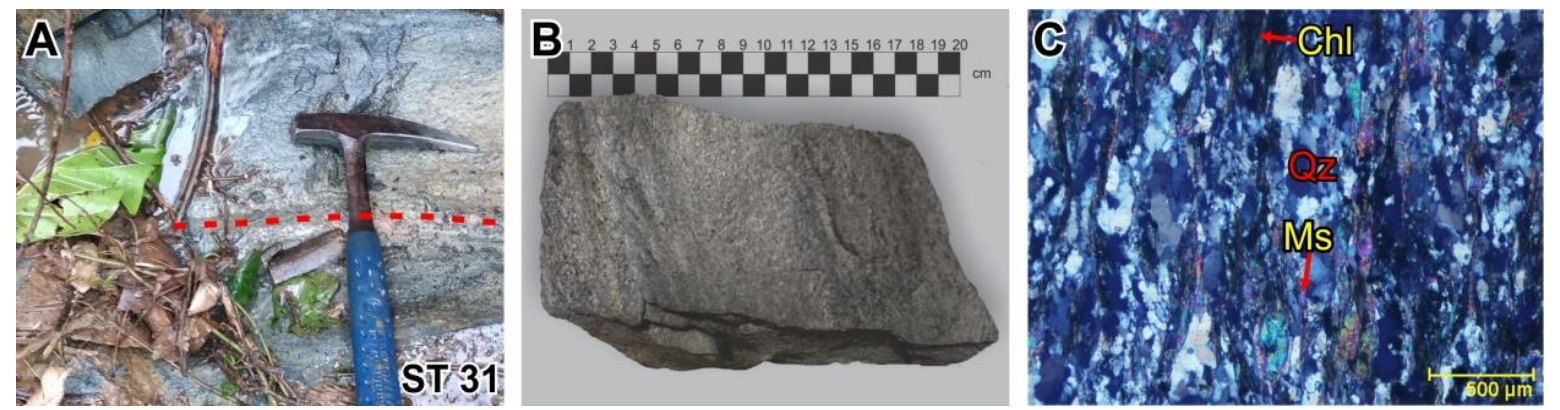

Gambar 3. Batuan metamorf dengan jenis sekis muskovit. (A) merupakan gambar singkapan, (B) merupakan gambar sampel hand specimen, dan (C) merupakan gambar sayatan tipis sampel batuan (nikol sejajar). Garis merah putus-putus menunjukkan foliasi pada singkapan. Ms= muskovit, Qz= kuarsa, dan Chl= klorit.
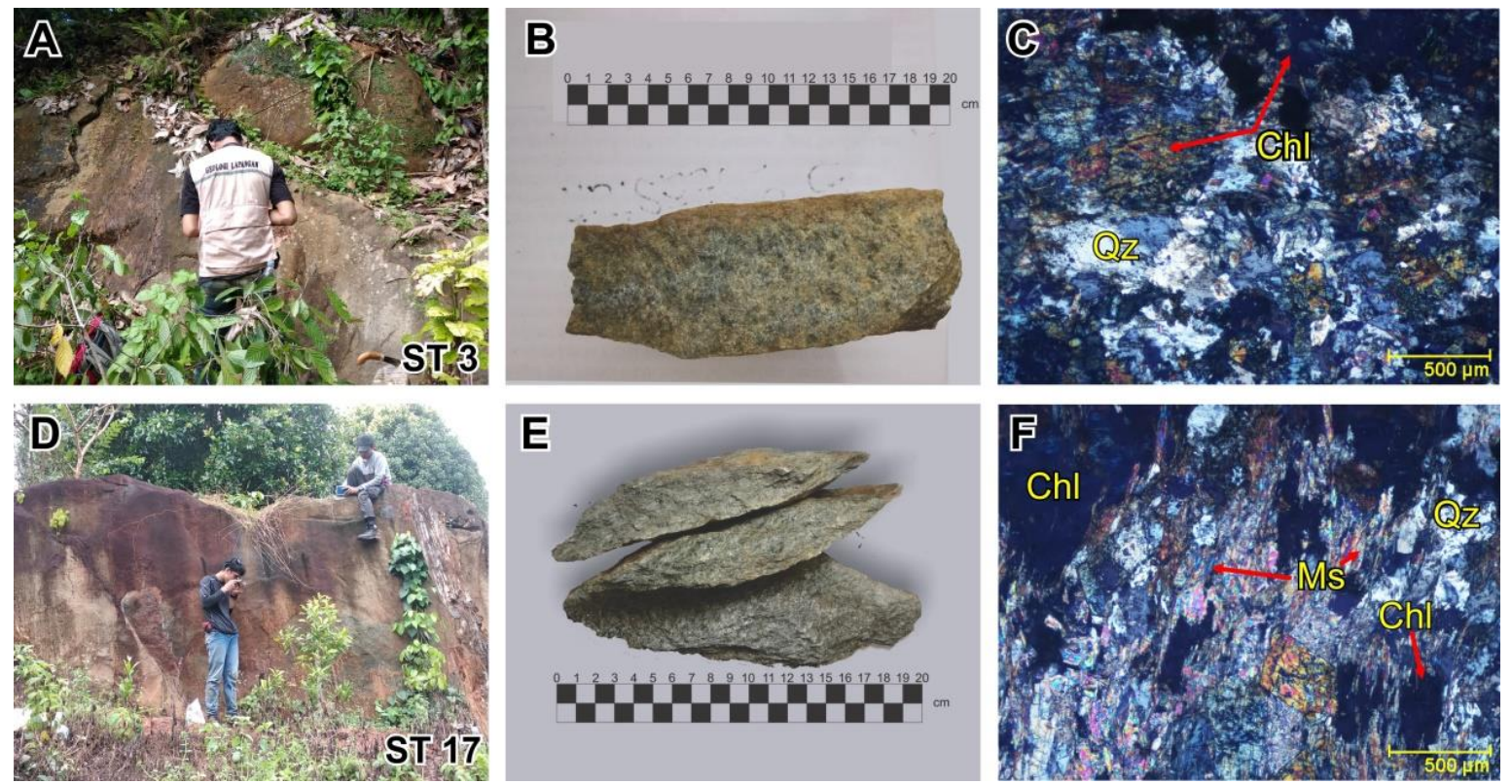

Gambar 4. Batuan metamorf dengan jenis sekis klorit. (A, D) merupakan gambar singkapan, (B, E) merupakan gambar sampel hand specimen, dan (C, F) merupakan gambar sayatan tipis sampel batuan (nikol sejajar). Ms= muskovit, $\mathrm{Qz}=$ kuarsa, dan $\mathrm{Chl}=$ klorit. 
oleh mineral kuarsa sehingga membentuk struktur skistosik. Pada batuan ini tidak dijumpai kehadiran mineral grafit.

\section{Sebaran Mineral Grafit}

Sebaran mineral grafit mencakup 50\% dari luas daerah penelitian yang meliputi bagian tengah hingga bagian selatan. Sebaran mineral grafit di daerah penelitian dibagi menjadi tiga kelas kisaran persentase kehadiran mineral grafit dalam batuan sekis muskovit. Kelas kisaran pertama yaitu memiliki kisaran kandungan mineral grafit $<25 \%$ pada batuan yang menempati bagian timur dan barat daerah penelitian. Kelas kisaran kedua memiliki kisaran kandungan mineral grafit 26\%-30\% pada batuan yang menempati bagian tengah daerah penelitian. Kelas kisaran ketiga memiliki kisaran kandungan mineral grafit $31 \%-52 \%$ pada batuan yang menempati bagian selatan daerah penelitian. Sebaran mineral grafit ini dapat dilihat pada Gambar 6 .

\section{Karakteristik Mineral Grafit}

Berdasarkan Robinson dkk. (2017) (Tabel 1), maka karakteristik mineral grafit di daerah penelitian memiliki beberapa karakteristik. Karakteristik mineral grafit berdasarkan tipe deposit dan kristalinitas, merupakan tipe komoditas serpih alami atau merupakan grafit alami (natural graphite), yang memiliki kristalinitas berupa kristalin yang berbentuk pipih atau menyerpih (Gambar 5). Hasil analisis SEM menunjukkan bahwa mineral grafit pada sekis muskovit di daerah penelitian memiliki kristal pipih yang berkembang baik dan memiliki ukuran butir lebih dari $20 \mu \mathrm{m}$ dengan ketebalan $\pm 1 \mu \mathrm{m}$ (Mitchell, 1993; Luque dkk., 2014; Kwiecińska and Petersen, 2004; Crossley, 2000; Yarangga dkk., 2017; Fogg dan Boyle, 1987).

Adapun karakteristik asal pembentukan mineral grafit pada daerah penelitian berdasarkan Robinson dkk. (2017) (Tabel 1) adalah merupakan produk dari metamorfisme regional dari sedimen karbon. Material sedimen yang mengandung karbon diindikasikan terendapkan dan mengalami metamorfisme regional yang dipengaruhi oleh faktor tekanan dan temperatur yang tinggi secara bersamaan dalam cakupan wilayah yang luas (Crossley, 2000).
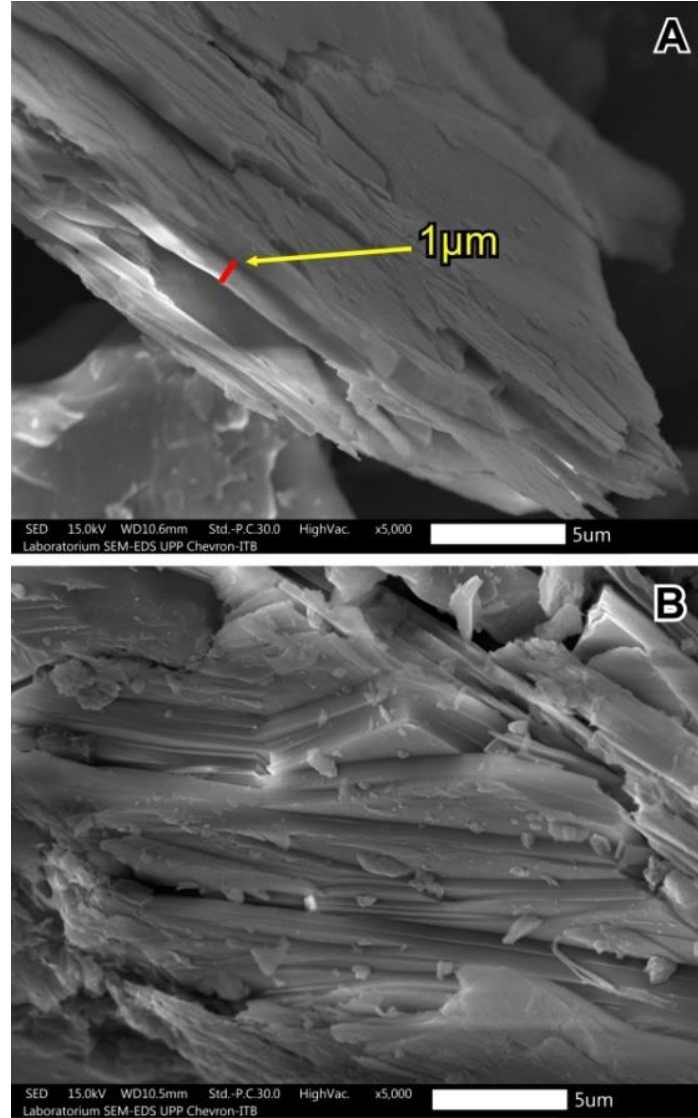

Gambar 5. Hasil Analisis SEM pada sampel batuan. (A) sampel batuan stasiun 25 yang memperlihatkan bentuk mineral grafit yang pipih atau menyerpih dengan ketebalan $\pm 1 \mu \mathrm{m}$. (B) sampel batuan stasiun 17 yang memperlihatkan mineral klorit.

Metamorfisme regional ini dicirikan dengan adanya mineral-mineral tekanan seperti mineral muskovit dan klorit yang merupakan mineral yang berasosiasi dengan mineral grafit yang pipih di daerah penelitian.

Berdasarkan hasil analisis megaskopos dan mikroskopis (petrografi) menunjukkan bahwa mineral grafit di daerah penelitian terbentuk pada fasies sekis hijau (Gambar 2, 3 dan Gambar 4). Dari hasil analisis tersebut, diperoleh kelompok mineral muskovit-klorit-kuarsa yang merupakan kelompok mineral yang terbentuk pada fasies sekis hijau yang terbentuk pada suhu 200-300 ${ }^{\circ} \mathrm{C} \quad$ (Widiaputra dkk., 2016) berdasarkan kehadiran mineral klorit.

Adapun karakteristik berdasarkan tubuh bijih (Robinson dkk., 2017) menunjukkan bahwa mineral grafit di daerah penelitian merupakan lapisan yang saling terikat, berbentuk tabular dan melensa serta pipih dengan panjang ribuan 


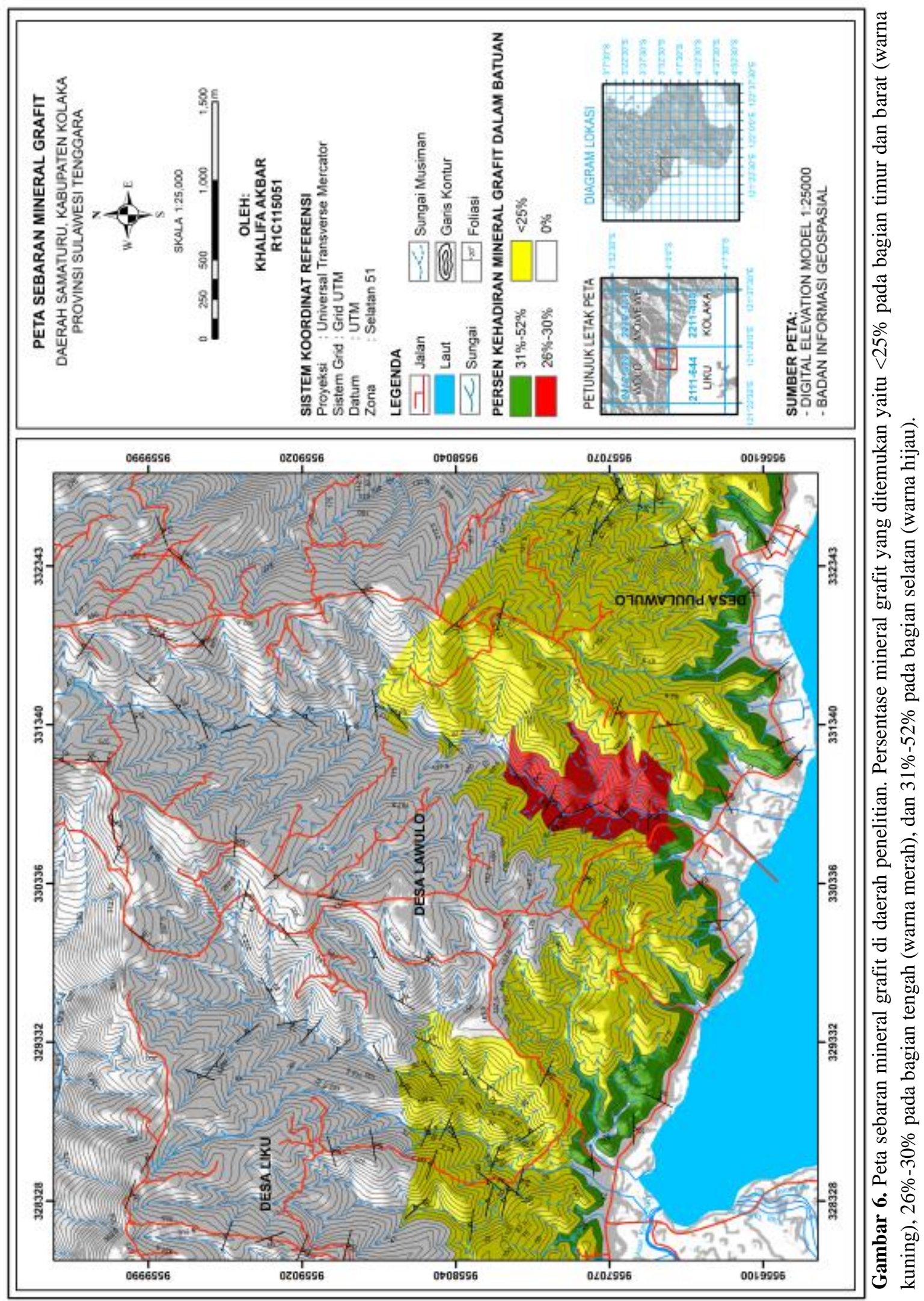



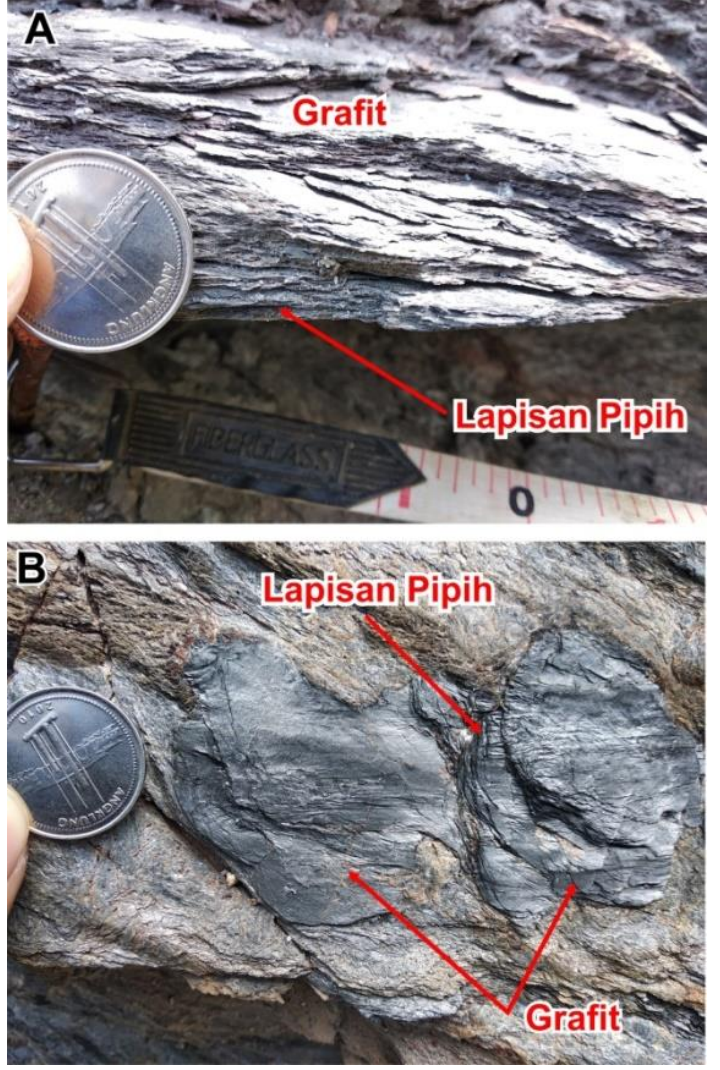

Gambar 7. Mineral grafit pada sekis muskovit yang berbentuk melensa yang pipih atau menyerpih dan membentuk lapisan yang saling terikat.

meter (Gambar 7). Hal ini diakibatkan oleh proses metamorfisme regional yang terjadi pada daerah ini. Hasil pengamatan lapangan menunjukkan mineral grafit di daerah penelitian membentuk ketebalan $\pm 10 \mathrm{~m}$ dengan panjang ribuan meter.

Sehubungan dengan karakteristik tubuh bijih, mineral grafit di daerah penelitian juga terdapat lapisan yang tidak teratur pada area hinge lipatan yakni terdapat pada kupasan jalan yang dijumpai membentuk pola yang tidak teratur pada beberapa titik (Gambar 8). Hal ini disebabkan oleh adanya struktur lipatan yang mengakibatkan mineral grafit yang membentuk lapisan-lapisan tipis yang saling terikat menjadi tidak beraturan pada area puncak pelengkungan sebuah lipatan (hinge fold) (Gambar 8).

Hasil analisis EDS (Gambar 9) menunjukkan adanya beberapa persenyawaan (compound) yang ditunjukkan oleh peak unsur yang muncul. Analisis ini digunakan untuk mengetahui kandungan unsur karbon pada sampel batuan. Sampel stasiun 25 mengandung persenyawaan (compound) karbon (C) dengan persentase $52,12 \%$, sedangkan pada hasil EDS pada sampel
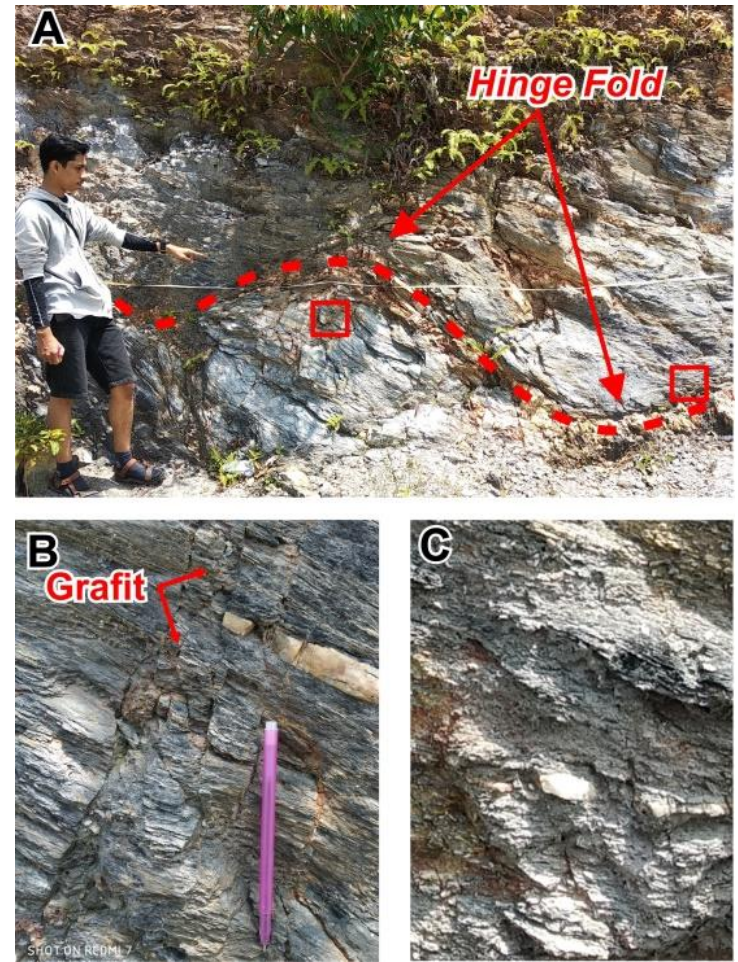

Gambar 8. Mineral grafit yang tidak teratur pada hinge lipatan. (A) gambar singkapan. (B) perbesaran gambar kotak berwarna merah pada antiklin dan (C) perbesaran gambar kotak berwarna merah pada sinklin.
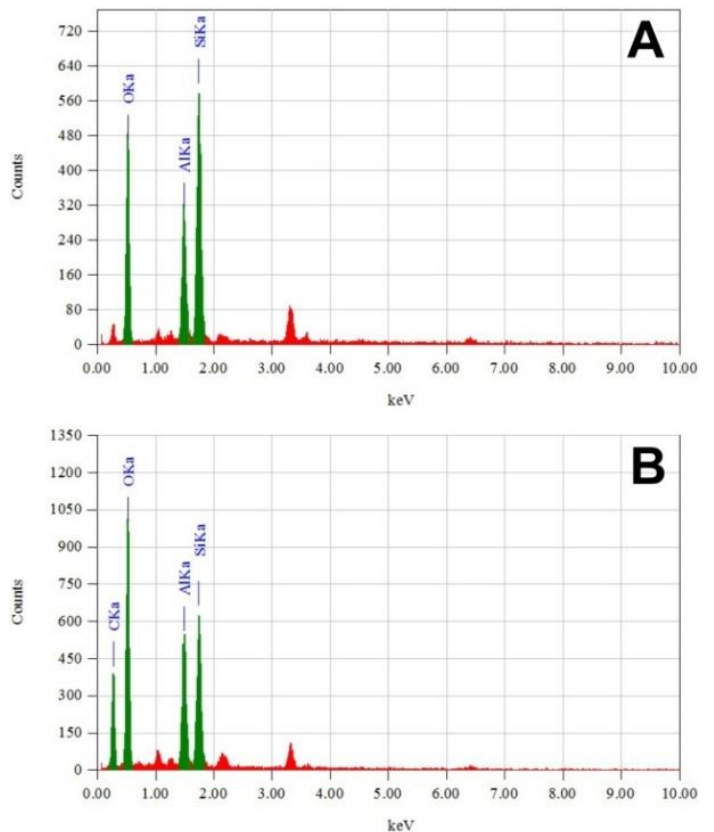

Gambar 9. Hasil analisis EDS pada sampel batuan. (A) stasiun 17 dan (B) stasiun 25.

stasiun 17 tidak mengandung unsur karbon (C) (Tabel 2). Persentase karbon grafit umumnya dipengaruhi oleh kandungan unsur karbon atau material organik pada awal sedimentasi. 
Hasil yang diperoleh dari analisis EDS dan petrografi, menunjukkan bahwa karakteristik mineral grafit berdasarkan tingkat bijih (persen karbon) (Robinson dkk. 2017) yaitu umumnya 5 hingga 30\% dan lebih tinggi secara lokal. Adapun persen karbon atas kehadiran mineral grafit di daerah penelitian berkisar antara $<25 \%$ $52 \%$. (Tabel 2).

Hasil analisis EDS diperoleh beberapa persenyawaan (compound) digunakan untuk mengetahui kandungan unsur karbon pada sampel batuan. Sampel stasiun 25 mengandung persenyawaan (compound) yang dibentuk oleh unsur-unsur tersebut membentuk karbon (C) dengan persentase $52,12 \%$, sedangkan pada hasil EDS pada sampel stasiun 17 tidak mengandung unsur karbon (C) (Tabel 2). Persentase karbon grafit umumnya dipengaruhi oleh kandungan unsur karbon atau material organik pada awal sedimentasi.

Tabel 2. Kandungan persentase (\%wt) dari sampel batuan.

\begin{tabular}{lcccccc}
\hline \multirow{2}{*}{ Sampel } & \multicolumn{6}{c}{ Persentase Unsur (\% wt) } \\
\cline { 2 - 7 } & $\mathrm{MgO}$ & $\mathrm{Al}_{2} \mathrm{O}_{a}$ & $\mathrm{SiO}_{2}$ & $\mathrm{CaO}$ & $\mathrm{Fe}_{2} \mathrm{O}_{3}$ & $\mathrm{C}$ \\
\hline St 17 & - & 27,99 & 72,01 & - & - & - \\
\hline St 25 & - & 19,76 & 28,13 & - & - & 52,12 \\
\hline
\end{tabular}

Berdasarkan karakteristik tipe deposit, kristalinitas, sifat dan bentuk kristalinitas, asal pembentukan, tubuh bijih dan tingkat bijih yang merujuk pada klasifikasi Robinson dkk. (2017) maka tipe endapan dari mineral grafit pada satuan sekis muskovit yang tersebar di daerah penelitian merupakan tipe endapan grafit serpih (flake graphite) (Mitchell, 1993; Luque dkk., 2014; Kwiecińska and Petersen, 2004; Crossley, 2000; Yarangga dkk., 2017; Fogg dan Boyle, 1987).

\section{KESIMPULAN}

Jenis batuan metamorf yang mengandung mineral grafit di daerah penelitian yaitu sekis muskovit. Sebaran mineral grafit di daerah Samaturu, Kabupaten Kolaka, Provinsi Sulawesi Tenggara yaitu tersebar pada bagian selatan dengan persentase $31-52 \%$, bagian tengah dengan persentase $26-30 \%$, dan pada bagian barat dan timur daerah penelitian dengan persentase $<25 \%$. Karakteristik dari mineral grafit di daerah Samaturu yaitu serpih diseminasi, kristalin, pipih atau menyerpih, produk dari metamorfisme regional pada fasies sekis hijau, membentuk lapisan yang saling terikat memiliki persentase karbon $<25 \%-52 \%$. Tipe endapan mineral grafit di daerah penelitian yaitu tipe grafit serpih atau (flake graphite).

\section{UCAPAN TERIMAKASIH}

Terima kasih kepada Kemenristek Dikti selaku instansi yang menjadi sumber dana untuk penelitian ini sebagai bagian dari pendanaan Program Kreativitas Mahasiswa (PKM) Tahun Anggaran 2019. Terima kasih kepada Ibu Dr. Hasria, S.Pd., M.Si dan kepada Bapak Suryawan Asfar, ST., M.Si yang telah membimbing dan memberi saran serta kritik hingga selesainya jurnal penelitian ini.

\section{DAFTAR PUSTAKA}

Anggriawan, R., 2016. Studi geologi Desa Kaloloa Kecamatan Samaturu Kabupaten Kolaka Provinsi Sulawesi Tenggara. Skripsi, tidak dipublikasikan. Universitas Halu Oleo.

Chaerul, M., 2017. Pengantar ilmu batuan. Teknik Geologi, Universitas Halu Oleo, Kendari. 154.

Crossley, P., 2000. Graphite high-tech supply sharpens up. Industrial Minerals, 398. hal.31-47.

Fogg, C.T., dan Boyle, E.H.J., 1987. Flake And High-Crystalline Graphite AvailabilityMarket Economy Countries. Washington: United States Bureau of Mines.

Hasria, Idrus, A., dan Warmada, I. W., 2017. The metamorphic rocks-hosted gold mineralization at Rumbia Mountains prospect area in the Southeastern arm of Sulawesi Island, Indonesia. Journal of Geoscience, Engineering, Environment, and Technology, 2, hal.217-223.

Hasria, Idrus, A., and Warmada, I. W., 2019. Alteration, mineralization and geochemistry of metamorphic rocks hosted hydrothermal gold deposit at Rumbia Mountains, Bombana Regency, Southeast Sulawesi, Indonesia, Journal of Geoscience, Engineering, Environment, and Technology, 4(2), hal.83-92.

Helmers, H., Sopaheluwakan, J., Nila, E. S., dan Tjokrosapoetro, S., $1989 . \quad$ Blueschist evolution in Southeast Sulawesi, Indonesia. Netherlands Journal of Sea Research, 24, hal.373-381.

Kwiecińska, B. dan Petersen, H.I., 2004. 
Graphite, semi-graphite, natural coke, and natural char classification-ICCP system. International Journal of Coal Geology, 57(2), hal.99-116.

Luque, F. J., Huizenga, J. M., Crespo-Feo, E., Wada, H., Ortega, L., dan Barrenechea, J. F., 2014. Vein graphite deposits: Geological settings, origin, and economic significance, Mineralium Deposita, 49(2), hal.261-277

Mitchell, C.J., 1993. Industrial mineral laboratory manual; flake graphite. United Kingdom: British Geological Survey.

Robinson, G. R. Jr., Hammarstrom, J.M., and Olson, D. W., 2017. Graphite, critical mineral resources of the united states economic and environmental geology and prospects for future supply. Professional Paper 1802, USGS Science Publishing Network Reston Publishing Service Center, Virginia.

Rusmana, E., Sukido, Sukarna, D., Haryono, E., dan Simandjuntak, T.O., 1993. Peta Geologi Lembar Lasusua-Kendari, Sulawesi, skala 1 : 250.000. Bandung: Pusat Penelitian dan Pengembangan Geologi.

Simandjuntak, T. O., Surono, dan Sukido, 1993. Peta Geologi Regional lembar Kolaka, Sulawesi, skala 1 : 250.000. Bandung: Pusat Penelitian dan Pengembangan Geologi.

Widiaputra, T., Patonah, A., dan Helmi, F., 2016. Penentuan Fasies Metamorfisme Pada Batuan Metamorf Bayah, Kabupaten Lebak, Propinsi Banten. Jatinangor: Universitas Padjadjaran.

Yarangga, A.A., Danisworo, C., Harjanto, A. , 2017. Studi grafit berdasarkan analisis petrografi dan SEM/EDX pada Daerah Windesi Kabupaten Teluk Wondama , Provinsi Papua. Prosiding Seminar Nasional XII "Rekayasa Teknologi Industri dan Informasi 2017", hal.185-191. 